\title{
MAGEA11 wt Allele
}

National Cancer Institute

\section{Source}

National Cancer Institute. MAGEA11 wt Allele. NCI Thesaurus. Code C91337.

Human MAGEA11 wild-type allele is located in the vicinity of Xq28 and is approximately 29 $\mathrm{kb}$ in length. This allele, which encodes melanoma-associated antigen 11 protein, plays a role in the modulation of androgen receptor-dependent gene transcription. 